\title{
Year-to-year Variations in Antioxidant Components of High-Lycopene Tomato (Solanum lycopersicum L.) Breeding Lines
}

\author{
Riadh Ilahy $^{1^{*}}$, Mohammed Wasim Siddiqui ${ }^{2}$, Gabriella Piro ${ }^{3}$, Marcello Salvatore Lenucci ${ }^{3}$, \\ Chafik Hdider ${ }^{1}$
}

${ }^{1}$ Laboratory of Horticulture, National Agricultural Research Institute of Tunisia, Tunis, Rue Hédi Karray 2049 Ariana, Tunisia ${ }^{2}$ Department of Food Science and Postharvest Technology, Bihar Agricultural University, Sabour, Bhagalpur, Bihar 813210, India ${ }^{3}$ Dipartimento di Scienze e Tecnologie Biologiche ed Ambientali, Università del Salento, Via Prov.le Lecce-Monteroni, 73100 Lecce, Italy A R T I C L E I N F O

Article history:

Received 25 January 2016

Accepted 04 May 2016

Available online, ISSN: 2148-127X

Keywords:

Antioxidant activity

$\beta$-carotene

Carotenoids

High-lycopene tomato genotypes

Flavonoids

${ }^{*}$ Corresponding Author:

E-mail: riadh.ilahy@iresa.agrinet.tn \begin{abstract}
A B S T R A C T
A two-year field study (2013-2014) was performed to evaluate phytochemical content and antioxidant activity of two high-lycopene tomato breeding lines (HLT-F71 and HLTF72) grown under open field conditions as compared to the traditional cultivar (cv) Rio Grande. Two open-field trials were conducted in 2013 and 2014. Three tomato cvs were used: two high-lycopene tomato advanced breeding lines (HLT-F71 and 'HLT-F72') (F7 generation), and the open-pollinated cv Rio Grande commonly grown in Tunisia. Regardless the growing years and cvs, lycopene content ranged from 98.8 to $280.0 \mathrm{mg} / \mathrm{kg}$ fw, total phenolics from 176.1 to $831.8 \mathrm{mg}$ GAE/kg fw flavonoids from 169.7 to 552.1 $\mathrm{mg} \mathrm{RE} / \mathrm{kg}$ fw and total vitamin C from 183.4 to $370.0 \mathrm{mg} / \mathrm{kg}$ fw. Significant year-to-year variability was only detected in total phenolics and flavonoid content. No significant year-to-year variability in antioxidant activity was detected in high-lycopene lines. Disregarding the cv, tomato berries harvested on July 2014 had $143 \%-224 \%$ higher total phenolics and $8 \%$ to $47 \%$ higher flavonoid contents compared to tomato berries harvested on July 2013. However, disregarding the cv, tomato berries harvested on July 2013 had $6 \%-17 \%$ higher lycopene and $8 \%-21 \%$ higher LAA compared to berries harvested on 2014. During the second growing year, the higher temperature, particularly prior to harvest, determined a decrease in lycopene content and a significant increase in total phenolics regardless the cv. Although the huge variability in total phenolics and the decrease in lycopene content during the second harvest, the antioxidant activity was not affected by year-to-year variability. This reveals consistent functional quality of these cvs and minimal genotype*environmental conditions interaction.
\end{abstract}

\section{Introduction}

Tomato (Solanum lycopersicum L.) berries, commonly consumed in the Mediterranean diet, offer a diverse mixture of nutrients that are essential for human nutrition and contribute to the promotion of good health and wellbeing. Increased consumption of fresh or processed tomato products (canned tomatoes, sauce, juice, ketchup, soup, etc.) is directly associated with a reduced risk of contracting several widespread human pathologies, including cardiovascular diseases, prostate, lung and stomach cancers, osteoporosis and UV radiations associated skin disorders (Erdman et al., 2009; Qu et al., 2013; Soares et al., 2014; Fernández-García 2014a, b). Flavonoids, phenols, ascorbic acid (vitamin C), tocochromanols (Vitamin E) and carotenoids, mainly lycopene, are important bioactive molecules of ripe tomato fruits (Lenucci et al., 2006; Ilahy et al., 2011a, b; 2015). These compounds synergizes to exert a positive effects on human health through oxidative and still not fully understood non-oxidative mechanisms (Erdman et al., 2009; Soares et al., 2014; Takashima et al., 2012;
Fernández-García 2014a, b). Consequently tomato fruits are increasingly considered as "functional food" (Ilahy et al., 2011a, b; Ilahy et al., 2015; Siddiqui et al., 2014).

Lycopene content represents $90 \%$ of the total pigments in ripe tomato fruits (Ilahy et al., 2011a, b). In vitro studies revealed that lycopene is 2 -fold and 10 -fold more effective in quenching reactive oxygen species than $\beta$-carotene and $\alpha$-tocopherol, respectively (Di Mascio et al., 1989) and has the highest Trolox Equivalent Antioxidant Capacity (TEAC) value among all carotenoids (Rice-Evans et al., 1997). This has stimulated development, by conventional breeding techniques, of a large number of new tomato lines with increased levels of lycopene (high-lycopene tomatoes) to satisfy the increasing demand of growers, processors and consumers for high nutritive quality food (Ilahy et al., 2009; Ilahy et al., 2016).

Different findings are reported regarding the functional quality of high-lycopene tomato cultivars (cvs) grown under open field conditions. Experiments 
conducted in the Mediterranean region (Tunisia, Italy and Israel) demonstrated consistent functional quality associated to satisfying horticulural performances (Lenucci et al., 2006; Hdider et al., 2013; Ilahy et al., 2011a, b; Levin et al., 2006). Lycopene concentration was at least two fold higher in red-ripe high-lycopene tomato cvs than in traditional cvs. However, experiments conducted in other regions reported low functional quality in recently developed tomato hybrids carrying $d g$ genes, known to increase considerably lycopene content (Siddiqui et al., 2014).

These different findings may be ascribed to many reasons; 1)most of the studies were conducted using plants from one year of harvest and without considering the likely diverse responses of different cvs (limited biological variability), 2) these cvs carry light-responsive high-pigment $(h p)$ mutations and modulate their photosynthetic activity accordingly, 3) the ongoing negative effects of climate change are a relevant topic for the Mediterranean basin which appears to be getting warmer and drier (Giorgi and Lionello 2008). Therefore, the aim of this study was to investigate the effect of the year-to-year variation on the functional quality of highlycopene tomato advanced breeding lines (HLT-F71 and HLT-F72) and the ordinary (Rio Grande) tomato cv grown simultaneously under open-field condition.

\section{Materials and methods}

\section{Plant Culture}

Trials were carried out in 2013 and 2014. Three tomato cvs were used: two high-lycopene tomato advanced breeding lines with the assigned names HLTF71 and 'HLT-F72' (F7 generation), selected by the National Agricultural Research Institute of Tunisia, and the open-pollinated cv Rio Grande (Petoseed, Saticoy, CA, USA) commonly grown in Tunisia. The highlycopene tomato cvs HLT-F71 and HLT-F72 have been developed through conventional plant-breeding techniques taking into account the careful selection of the high-lycopene trait (Ilahy et al., 2016).

Seeds were sown on 13 February 2013 and 20 February 2014. Seedlings were transplanted in an openfield at the National Agricultural Research Institute of Tunisia (36 $\left.500^{\prime} 40.791^{\prime} \mathrm{N} ; 10^{\circ} 11^{\prime} 13.795^{\prime} \mathrm{E}\right)$ with a spacing of approximately $0.4 \mathrm{~m}$ within the row and $1.5 \mathrm{~m}$ between rows, matching a density of about 16,667 plants/ha and grown to maturity. The experimental design was a randomised complete block with three blocks (replicates). Irrigation was applied using a drip method with $4 \mathrm{~L} \mathrm{~h}^{-1}$ drippers placed at $0.4 \mathrm{~m}$ intervals along the irrigation line. Standard agronomical techniques were used for drip irrigation, plant nutrition and pathogen prevention as described by Ilahy et al. (2011a). For each trial, all cvs under analysis were grown simultaneously and subjected to identical treatments and, obviously, environmental conditions in order to minimize the influence of pre- and post-harvest factors, agronomic and cultural practices, ripening stage at harvest and storage conditions on genotype-related variability (Abushita et al., 2000; Dumas et al., 2003; George et al., 2004).

\section{Fruit Sampling}

Tomato fruits were hand harvested randomly from the rows and from the middle of the plant of each block at the red-ripe stage and delivered quickly to the laboratory. Fully ripe healthy tomato berries, homogeneous for intense red-colour and size, blemish free were visually selected (at least $2 \mathrm{~kg}$ for each $\mathrm{cv}$ and for each block). Tomato fruits were cut into small pieces and homogenized in a mixer (Waring Laboratory \& Science, Torrington, CT, US). The obtained juice was frozen at $20^{\circ} \mathrm{C}$ and used to determine total carotenoids, lycopene, total phenols, flavonoids, total vitammin $\mathrm{C}$ contents as well as the HAA and LAA within less than one week, in order to minimize the depletion of nutrients that inevitably occurs even during frozen homogenate storage (Phillips et al., 2010).

\section{Analytical Procedures}

Determination of lycopene content: Lycopene extraction and determination was conducted as described by Fish et al. (2002) on triplicate independent aliquots $(0.3 \mathrm{~g})$ of the homogeneous suspension. The method uses a mixture of hexane/ethanol/acetone (2:1:1 by vol.) containing $0.05 \%$ butylated hydroxytoluene (BHT). During the extraction process, some precautions were taken, like working in a reduced luminosity room and wrapping glass materials in aluminium foil to avoid lycopene loss by photo-oxidation. For lycopene quantification, the absorbance of the hexane extract was read at $503 \mathrm{~nm}$ using a Cecil BioQuest CE 2501 spectrophotometer (Cecil Instruments Ltd., Cambridge, UK). Lycopene molar extinction $\varepsilon=17.210^{4} \mathrm{M}^{-1} \mathrm{~cm}^{-1}$ in $\mathrm{n}-$ hexane was used for lycopene content determination and results were expressed as $\mathrm{mg} / \mathrm{kg}$ fresh weight (fw).

Determination of total phenol content: Total phenols were extracted as described by Martínez-Valverde et al. (2002) on triplicate independent aliquots $(0.3 \mathrm{~g})$ of the homogeneous suspension. Briefly, $5 \mathrm{~mL}$ of $80 \%$ aqueous methanol and $50 \mu \mathrm{L}$ of $37 \% \mathrm{HCl}$ were added to each sample. The extraction was performed at $4{ }^{\circ} \mathrm{C}$, for $2 \mathrm{~h}$, under constant shaking $(300 \mathrm{rpm})$. Samples were centrifuged at $10000 \mathrm{~g}$ for $15 \mathrm{~min}$. The total phenols assay was performed by using the Folin-Ciocalteu reagent as described by Spanos and Wrolstad (1990) on triplicate 50 $\mu \mathrm{L}$ aliquots of the supernatant. The absorbance was read at $750 \mathrm{~nm}$ using a Cecil BioQuest CE 2501 spectrophotometer (Cecil Instruments Ltd., Cambridge, UK). The linear reading of the standard curve was from 0 to $300 \mu \mathrm{g}$ gallic acid equivalent $\mathrm{mL}^{-1}$. Results were expressed in $\mathrm{mg}$ of gallic acid equivalent (GAE) $/ \mathrm{kg}$ fw.

Determination of total flavonoid content: The total flavonoid content was determined as described by Zhishen et al. (1999) on triplicate independent aliquots $(0.3 \mathrm{~g})$ of the homogeneous suspension. The resulting methanolic extract $(50 \mu \mathrm{L}$ aliquots) was used for determination of total flavonoids. Samples were diluted with distilled water to a final volume of $0.5 \mathrm{~mL}$, and 30 
$\mu \mathrm{L}$ of $5 \% \mathrm{NaNO}_{2}$ was added. After $5 \mathrm{~min}, 60 \mu \mathrm{L}$ of $10 \%$ $\mathrm{AlCl}_{3}$ was added and finally $200 \mu \mathrm{L}$ of $1 \mathrm{M} \mathrm{NaOH}$ was added after $6 \mathrm{~min}$. The absorbance was read at $510 \mathrm{~nm}$ in a Cecil BioQuest CE 2501 spectrophotometer (Cecil Instruments Ltd., Cambridge, UK). The linear reading of the standard curve was from 0 to $250 \mu \mathrm{g}$ rutin $\mathrm{mL}^{-1}$ and total flavonoid content was expressed as $\mathrm{mg}$ of rutin equivalent $(\mathrm{RE}) / \mathrm{kg}$ fw.

Total vitamin C content: Total vitamin C (AsA + DHA) content was determined as reported by Kampfenkel et al. (1995) on triplicate samples of the homogeneous suspension $(0.1 \mathrm{~g})$. AsA and DHA were extracted using $6 \%$ metaphosphoric acid and detected at 525nmin a spectrophotometer (Cecil BioQuest CE 2501) and expressed in $\mathrm{mg} / \mathrm{kg}$ fw. The linear reading of the standard curve was from 0 to $700 \mu \mathrm{mol}$ AsA.

Hydrophilic and lipophilic antioxidant activity assay: The measurement of the hydrophilic and lipophilic antioxidant actvity (HAA and LAA, respectively) was performed using the TEAC assay. The antioxidant activity was measured using the ABTS decoloration method (Pellegrini et al., 2007). The TEAC assay is standardly used for antioxidant activity assessement of fruit and vegetables, its numerous advantages consist in reproducibility, simplicity, and a good estimate of the antioxidant activity of pure compounds and complex matrices (Thaipong et al., 2006; Pellegrini et al., 2007). Hydrophilic and lipophilic antioxidants were extracted from $0.3 \mathrm{~g}$ of the homogeneous suspension (three independent replicates) with $50 \%$ methanol or $50 \%$ acetone, respectively, at $4^{\circ} \mathrm{C}$ under constant shaking (300 $\mathrm{rpm}$ ) for $12 \mathrm{~h}$. Samples were centrifuged at $10000 \mathrm{~g}$ for 7 min. Supernatants were recovered and used for antioxidant activity measurements. The antioxidant activities were measured at $734 \mathrm{~nm}$ in a Cecil BioQuest CE 2501 spectrophotometer (Cecil Instruments Ltd., Cambridge, UK). Two different calibration curves were constructed using freshly prepared trolox solutions for HAA and LAA determinations. The linear reading of the standard curves was from 0 to $16 \mu \mathrm{M}$ Trolox for both HAA and LAA. Values were expressed as $\mu \mathrm{M}$ of Trolox/100 g of fw.

\section{Statistical Analysis}

The year-to-year variations in the nutritional properties of the red-ripe berries of the ordinary Rio Grande tomato $\mathrm{cv}$ and the two high-lycopene tomato advanced breeding lines (HLT-F71 and HLT-F72) were assessed by analysis of variance (ANOVA). When a significant difference was detected, means were compared using the least significant difference (LSD) test $(\mathrm{P}<$ 0.05). All statistical comparisons were performed using SAS Version 6.1 software (SAS Institute, Cary, NC, USA). Correlations were performed using Pearson's correlation coefficient (r).

\section{Results and discussion}

\section{Climatic Data}

Climatic data including temperature $\left(\mathrm{T}^{\circ} \mathrm{C}\right.$ : $\min , \max$, average), relative humidity (RH: min, max, average) and rainfall $(\mathrm{mm})$ are presented in figure 1. During the two years 2013 and 2014, temperatures and relative humidity $(\mathrm{RH})$ have the same pattern of variation. At the beginning of the cycle, the temperature values are between 10 and $15^{\circ} \mathrm{C}$ to stabilize at around $30^{\circ} \mathrm{C}$ at the stage of harvesting. The $\mathrm{RH}$ values are between $75^{\circ} \mathrm{C}$ and $60^{\circ} \mathrm{C}$ during the summer. The same seasonal pattern was observed for rainfall with an exceptional event exceeding $20 \mathrm{~mm}$ recorded in April 2013.
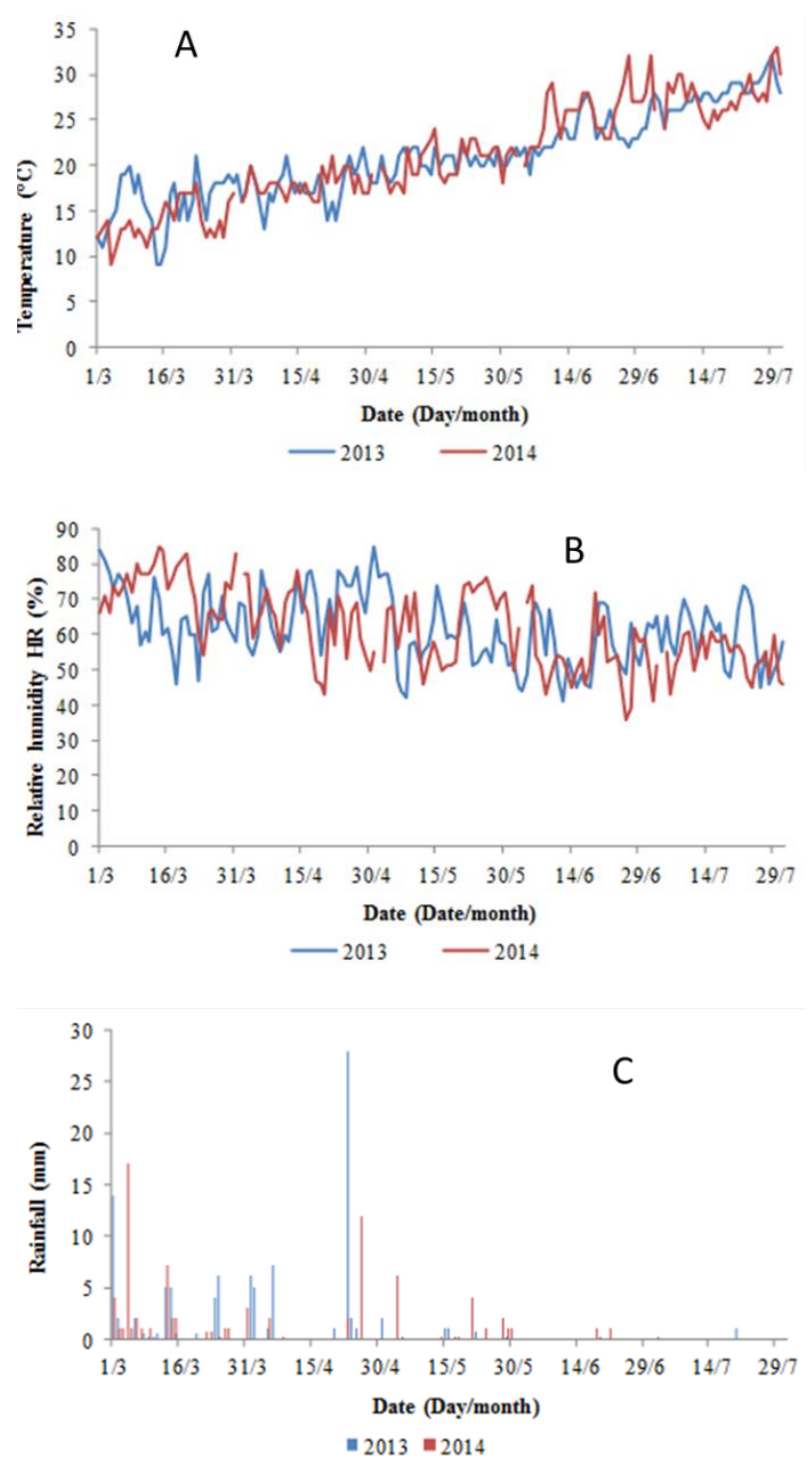

Figure 1 Climatic data: A/Temperature $\left(\mathrm{T}^{\circ} \mathrm{C}: \min , \max\right.$, average), $\mathrm{B} /$ relative humidity (RH: $\min , \max$, average) and $\mathrm{C} /$ rainfall (mm) during the 2013 and 2014 growing seasons. 


\section{Lycopene Content}

The amounts of lycopene, total phenolics, total flavonoids and total vitamin $\mathrm{C}$ in the ordinary Rio Grande and the high-lycopene 'HLT-F71' and 'HLT-F72' tomato breeding lines are reported in table 1. Lycopene content was not significantly influenced by the growing year $(\mathrm{P}>$ 0.05). Lycopene content in tomato fruit harvested on July 2013 ranged from $104.9 \mathrm{mg} / \mathrm{kg}$ fw in Rio Grande to 280.0 $\mathrm{mg} / \mathrm{kg}$ fw in HLT-F71. This content was lower in tomato berries harvested on July 2014 and ranged from 98.8 in Rio Grande to $239.1 \mathrm{mg} / \mathrm{kg}$ fw in HLT-F71. Therefore, compared to Rio Grande, variation ranging from $67 \%$ to $166 \%$ and from $54 \%$ to $141 \%$ in lycopene content was noticed during the first and the second harvest respectively. In addition, compared to the growing season 2014, fruit harvested on July 2013 had 6\% - 17\% higher lycopene regardless the $\mathrm{cv}$. The decrease in lycopene accumulation potential in tomato cvs can be ascribed mainly to differences in temperature. In fact, the prolonged heat stress may have been responsible for the low lycopene content of the fruits harvested on July 2014 This is in agreement with Brandt et al., (2006) who focused on the effect of environmental conditions on lycopene content and colour of ripening tomatoes and reported that the biosynthesis of lycopene is inhibited if the temperature of the fruits exceeds $30{ }^{\circ} \mathrm{C}$ (Please cite lit. Because stress, especially heat, increase lycopene content). The high-lycopene tomato breeding lines showed the highest lycopene content. When compared to Rio Grande, 68-167\% and 54-142\% increases in lycopene content were observed during the first and the second harvest respectively. Across the two years, we observed a significantly higher amount of lycopene in 2013 compared to 2014 .

The obtained values are in the range reported recently by Ilahy et al., (2011a, b; 2016) and Lenucci et al., (2006) ranging from 28 to $893 \mathrm{mg} / \mathrm{kg}$ fw measured in different tomato cvs grown under open field conditions from different geographical areas.

Tomato $h p$ mutations are best known to raise not only lycopene levels in red-ripe tomato berries (Mochizuki and Kamimura, 1984; Wann et al., 1985; Levin et al., 2006; Ilahy et al., 2016) but also the content of other plastidaccumulating metabolites (Lenucci et al., 2006; Ilahy et al., 2011b). The massive accumulation of these valuable compounds can be ascribed to a complex combination of factors comprising a superior biosynthetic and accumulation/sequestration potential of the metabolites in these cvs than in the traditional ones (Lenucci et al., 2012).

\section{Total Phenolics and Flavonoid Content}

Total phenolics and flavonoid contents were significantly influenced by the growing year as shown in Table $1(\mathrm{P}<0.05)$. Total phenolic content in tomato fruit harvested on July 2013 ranged from $176.1 \mathrm{mg} / \mathrm{kg}$ fw in Rio Grande to $265.2 \mathrm{mg} / \mathrm{kg}$ fw in HLT-F71. Significant increase in the total phenolics content was detected in all the tomato cvs during the second year of harvest. Total phenolics content ranged from $454.7 \mathrm{mg} \mathrm{GAE} / \mathrm{kg} \mathrm{fw}$ in Rio Grande to $831.9 \mathrm{mg}$ GAE/kg fw in HLT-F71. Therefore, compared to Rio Grande, variation ranging from $32 \%$ to $45 \%$ and from $24 \%$ to $82 \%$ in total phenolics content were observed during the first and the second harvest respectively. In addition, compared to the growing season 2013, fruit harvested on July 2014 had 143\% to $224 \%$ higher total phenolics regardless the cv. Total phenolics values were in accordance with those of Ilahy et al. (2011a, b), Hdider et al., (2013) and Ilahy et al., (2016) ranging from 105 to $877 \mathrm{mg}$ GAE/kg fw in different highlycopene tomato cvs depending on the ripening stage, from 105.8 to $394.5 \mathrm{mg} \mathrm{GAE} / \mathrm{kg}$ fw at the red-ripe stage depending on the $\mathrm{cv}$ and from 216.1 to $641.8 \mathrm{mg} \mathrm{GAE} / \mathrm{kg}$ fw depending on the fraction. Higher values ranging from 1200 to $1330 \mathrm{mg} \mathrm{GAE} / \mathrm{kg}$ fw were reported by Lenucci et al. (2006) for red-ripe berries of high-pigment tomato cvs grown in Southern Italy. Nevertheless, lower values ranging from 87 to $177 \mathrm{mg} \mathrm{GAE} / \mathrm{kg}$ fw in the pulp of different tomato cvs from different geographical areas were reported (Toor and Savage 2005; Chandra and Ramalingam 2011; Chandra et al. 2012).

Flavonoid content was also significantly influenced by the growing year $(\mathrm{P}<0.05)$. Flavonoid content ranged from $169.7 \mathrm{mg} \mathrm{RE} / \mathrm{kg}$ fw to $375.9 \mathrm{mg} \mathrm{RE} / \mathrm{kg}$ fw and from $184.5 \mathrm{mg} / \mathrm{kg}$ fw to $552.1 \mathrm{mg} / \mathrm{kg}$ fw in tomato berries harvested on July 2013 and 2014 respectively. Therefore, compared to Rio Grande, flavonoid content was $86 \%$ to $120 \%$ and $23 \%$ to $199 \%$ higher during the growing season 2013 and 2014 respectively. Compared to the growing season 2013, fruit harvested on July 2014 had $8 \%$ to $47 \%$ higher flavonoid content regardless the cv. Recently Ilahy et al. (2011a, b) Hdider et al. (2013) and Ilahy et al., (2016) reported flavonoid content values ranging from 105.6 to $590.6 \mathrm{mg} \mathrm{RE} / \mathrm{kg} \mathrm{fw}$ in different high-lycopene tomato cvs depending on the ripening stage, from 105.6 to $394.5 \mathrm{mg} \mathrm{RE} / \mathrm{kg}$ fw at the red-ripe stage depending on the $\mathrm{cv}$ and from 222 to $783 \mathrm{mg} \mathrm{RE} / \mathrm{kg}$ fw depending on the fraction.

The flavonoid values obtained are much higher when compared to those of the ordinary tomato cv Rio Grande and Donald grown under different growing conditions ranging from 120.2 to $133 \mathrm{mg} \mathrm{RE} / \mathrm{kg}$ fw.

The massive total phenolics and flavonoid accumulation in $h p$ tomato $\mathrm{cv}$ during the 2014 growing season can be ascribed to: 1) the high-lycopene trait, in fact, in red-ripe tomato fruits, naturally carrying mutations that increase carotenoid content, such as high pigment ( $\left.h p-1, h p-1^{w}, h p-2, h p-2^{j}, h p-2^{d g}\right)$ mutations, are also characterized by a dramatic increase in plastid biogenesis and in the production of other compounds such as flavonoids and vitamin C (Mochizuki and Kamimura, 1984; Mustilli et al. 1999; Bino et al. 2005), 2) the prolonged heat stress conditions during the 2014 growing seasons which may induced a decrease in lycopene content and an accumulation of both total phenolics and flavonoids to overcome those particular conditions. 
Table 1 Phytochemical content in high-lycopene tomato breeding lines and Rio Grande grown in 2013 and 2014

\begin{tabular}{l|ccll}
\hline \multicolumn{1}{c|}{ Analysis } & Growing year & HLT-F71 & HLT-F72 & Rio Grande \\
\hline Lycopene & 2013 & $280.0 \pm 10.0 \mathrm{a}$ & $176.2 \pm 9.7 \mathrm{a}$ & $104.9 \pm 7.5 \mathrm{a}$ \\
(mg/kg fw) & 2014 & $239.1 \pm 10.3 \mathrm{a}$ & $152.6 \pm 5.0 \mathrm{a}$ & $98.8 \pm 5.2 \mathrm{a}$ \\
Total phenolics & 2013 & $256.2 \pm 18.2 \mathrm{~b}$ & $233.8 \pm 19.3 \mathrm{~b}$ & $176.1 \pm 11.2 \mathrm{~b}$ \\
(mg/kg fw) & 2014 & $831.8 \pm 81.1 \mathrm{a}$ & $568.4 \pm 21.8 \mathrm{a}$ & $454.7 \pm 23.3 \mathrm{a}$ \\
Flavonoids & 2013 & $375.1 \pm 33.0 \mathrm{~b}$ & $315.9 \pm 20.6 \mathrm{a}$ & $169.7 \pm 17.4 \mathrm{a}$ \\
(mg ER/kg fw) & 2014 & $552.11 \pm 25.24 \mathrm{a}$ & $228.7 \pm 15.9 \mathrm{~b}$ & $184.5 \pm 4.4 \mathrm{a}$ \\
Total vitamin C & 2013 & $212.21 \pm 18.62 \mathrm{a}$ & $370.1 \pm 24.0 \mathrm{a}$ & $183.4 \pm 7.9 \mathrm{a}$ \\
(mg/kg fw) & 2014 & $328.31 \pm 41.09 \mathrm{a}$ & $317.6 \pm 13.6 \mathrm{a}$ & $206.2 \pm 3.1 \mathrm{a}$ \\
\hline
\end{tabular}

Table 2 Hydrophilic and lipophilic antioxidant activity in high-lycopene tomato breeding lines and Rio Grande grown in 2013 and 2014

\begin{tabular}{l|clll}
\hline Antioxidant activity & Growing year & HLT-F71 & HLT-F72 & Rio Grande \\
\hline \multirow{2}{*}{ HAA $(\mu \mathrm{M}$ Trolox/100 $\mathrm{g} \mathrm{fw})$} & 2013 & $279.4 \pm 3.5 \mathrm{a}$ & $235.8 \pm 15.3 \mathrm{a}$ & $116.7 \pm 8.4 \mathrm{~b}$ \\
& 2014 & $287.1 \pm 7.8 \mathrm{a}$ & $178.2 \pm 1.1 \mathrm{a}$ & $169.3 \pm 2.4 \mathrm{a}$ \\
\hline \multirow{2}{*}{ LAA $(\mu \mathrm{M}$ Trolox/100 $\mathrm{g} \mathrm{fw})$} & 2013 & $387.6 \pm 16.4 \mathrm{a}$ & $249.2 \pm 12.6 \mathrm{a}$ & $146.0 \pm 8.6 \mathrm{a}$ \\
& 2014 & $319.6 \pm 8.2 \mathrm{a}$ & $229.1 \pm 6.2 \mathrm{a}$ & $134.9 \pm 3.2 \mathrm{a}$ \\
\hline
\end{tabular}

Table 3 Pearson correlation coefficients ( $r$ ) and related significance between antioxidant content and antioxidant activities

\begin{tabular}{l|cccc}
\hline \multicolumn{1}{c|}{ TEAC assay } & \multicolumn{2}{c}{2013} & & 2014 \\
\hline Compounds & $\mathrm{r}$ & $\mathrm{P}$ & $\mathrm{r}$ & $\mathrm{P}$ \\
\hline & & Hydrophilic fraction & \\
Total vitamin C & 0.38 & $\mathrm{~ns}$ & 0.60 & $\mathrm{~ns}$ \\
Total phenolics & 0.81 & $<0.01$ & 0.90 & $<0.01$ \\
Flavonoids & 0.83 & $<0.01$ & 0.93 & $<0.01$ \\
\hline & & Lipophilic fraction & & $<0.01$ \\
Lycopene & 0.98 & $<0.01$ & 0.95 & \\
\hline
\end{tabular}

$\mathrm{n}($ sample size $)=21(\mathrm{~ns}=$ no significant correlation $)$

\section{Total Vitamin C Content}

Total vitamin $\mathrm{C}$ content was not significantly influenced by the growing year as shown in Table $1(\mathrm{P}>$ 0.05). Total vitamin $\mathrm{C}$ in tomato berries harvested on July 2013 ranged from $183.4 \mathrm{mg} / \mathrm{kg}$ fw in Rio Grande to 370.1 $\mathrm{mg} / \mathrm{kg}$ fw in HLT-F72. On July 2014, total vitamin C content ranged from $206 \mathrm{mg} / \mathrm{kg}$ fw in Rio Grande to 328 $\mathrm{mg} / \mathrm{kg}$ fw in HLT-F71. Therefore, compared to Rio Grande, variation ranging from $15 \%$ to $101 \%$ and from $54 \%$ to $59 \%$ in total vitamin C content were observed during the first and the second harvest respectively. Compared to the growing season 2013, HLT-F71 and Rio Grande fruit harvested on July 2014 had 12\% and 54\% higher total vitamin $\mathrm{C}$ compared to Rio Grande. Ilahy et al., (2016) reported that total vitamin $\mathrm{C}$ content in different tomato fraction ranged from 138.6 to 497.8 $\mathrm{mg} / \mathrm{kg}$ fw. Similar increase in vitamin C contents was reported for the photomorphogenic tomato mutants ( $h p-1$ and $h p-2)$ by Mochizuki and Kamimura 1984 and Mustilli et al. 1999. The amounts of total vitamin $\mathrm{C}$ in highlycopene tomato berries were similar to previous studies on field-grown $h p$ tomato ranging from 125 to $333 \mathrm{mg} / \mathrm{kg}$ fw (Lenucci et al., 2006; Ilahy et al. 2011a).

\section{Hydrophilic and Lipophilic Antioxidant Activity}

The hydrophilic and lipophilic antioxidant activities determined using the TEAC assay are reported in Table 2. Only the HAA was significantly influenced by the growing year $(\mathrm{P}<0.05)$. The HAA in tomato berries harvested on July 2013 ranged from $116.8 \mu \mathrm{M}$ Trolox/100 $\mathrm{g}$ fw in Rio Grande to $266.1 \mu \mathrm{M}$ Trolox/100 $\mathrm{g}$ fw in HLTF71. However, in tomato berries harvested on July 2014, the HAA ranged from $169.3 \mu \mathrm{M}$ Trolox $/ 100 \mathrm{~g}$ fw in Rio Grande to $279.4 \mu \mathrm{M}$ Trolox/100 $\mathrm{g}$ fw in HLT-F71. Therefore compared to Rio Grande, variation ranging from $58 \%$ to $128 \%$ and from $5 \%$ to $65 \%$ were recorded during the growing seasons 2013 and 2014 respectively. Compared to the 2013 growing season, the HAA was $5 \%$ to $44 \%$ higher in HLT-F71 and Rio Grande but was $3 \%$ lower in HLT-F71. The contribution of the HAA to the total antioxidant activity ranged from $40 \%$ to $46 \%$ and from $43 \%$ to $64 \%$ during the 2013 and 2014 growing seasons respectively.

Our results are in line with those of Ilahy et al. (2011a) and Hdider et al. (2013) ranging from 166 to $488.6 \mu \mathrm{M}$ Trolox/100 $\mathrm{g}$ fw for different high-lycopene tomato cvs harvested at different ripening stages. Ilahy et al. (2011b) reported values ranging from 498.4 to 572.1 
$\mu \mathrm{M}$ Trolox/100 $\mathrm{g}$ fw for different high-lycopene tomato cvs harvested at the red-ripe stage.

Regarding LAA, values ranged from $146.0 \mu \mathrm{M}$ Trolox/100 g fw in Rio Grande to $387.6 \mu \mathrm{M}$ Trolox/100 g fw in HLT-F71 during the 2013 growing season and from 134.9 $\mu \mathrm{M}$ Trolox/100 $\mathrm{g}$ fw to $319.6 \mu \mathrm{M}$ Trolox/100 $\mathrm{g}$ fw in HLT-F71. Therefore, compared to Rio Grande, variations ranging from $70 \%$ to $165 \%$ and from $69 \%$ to $136 \%$ were recorded during the growing seasons 2013 and 2014 respectively. Compared to the 2014 growing season, the LAA was $8 \%$ to $21 \%$ higher regardless the cv.

Our results are in line with those of Ilahy et al. (2011a) and Hdider et al. (2013) ranging from 139 to $488.6 \mu \mathrm{M}$ Trolox per $100 \mathrm{~g}$ fw for different high-lycopene tomato cvs harvested at different ripening stages. Ilahy et al. (2011b) reported values ranging from 348.8 to 540.1 $\mu \mathrm{M}$ Trolox per $100 \mathrm{~g}$ fw for different high-lycopene tomato cvs harvested at the red-ripe stage. Lower LAA mean values were reported by Toor and Savage, (2005) of $20 \mu \mathrm{M}$ Trolox per $100 \mathrm{~g}$ fw in the peel, $7 \mu \mathrm{M}$ Trolox per $100 \mathrm{~g}$ fw in the pulp and $10.9 \mu \mathrm{M}$ Trolox per $100 \mathrm{~g}$ fw in the seed. Ilahy et al., (2016) reported that the LAA in different open field grown tomato fraction ranged from 139.9 to $632.4 \mu \mathrm{M}$ Trolox/100 $\mathrm{g}$ fw.

\section{Correlations}

Considering data from all tomato cvs, highly significant correlations between LAA values and lycopene content $(\mathrm{r}=0.89 ; \mathrm{P}<0.01)$ and $(\mathrm{r}=0.95 ; \mathrm{P}<$ 0.01 ) in 2013 and 2014 growing years respectively were obtained (Table 3). This is in agreement with the well recognized fact that LAA of tomato fruits was mainly attributed to the presence of carotenoids particularly lycopene (Lenucci et al., 2006; Ilahy et al., 2016).

Regarding the hydrophilic fraction (Table 3), and considering our data, no significant correlations between HAA values and total vitamin $\mathrm{C}$ was found in 2013 and 2014 growing seasons $(\mathrm{r}=0.38 ; \mathrm{P}>0.05$ and $\mathrm{r}=0.60 ; \mathrm{P}$ $>0.05$ respectively). This may be due to the fact that the hydrophilic extract contains other compounds that influence the antioxidant activity. Kahkonen et al. (1999) reported that the antioxidant capacity might not always correlate with the amount of phenols. Moreover, Raffo et al. (2002) found that the correlation of the HAA values to phenols depends on the simple phenol composition. In fact, HAA value was correlated to caffeic acid but not to chlorogenic acid, p-coumaric acid, rutin, quercetin or naringenin. The lack of correlation could be due to the content of total phenolics and flavonoids, which may account for most of the HAA value. In fact, there was a good significant correlation between HAA values and total phenolics $(\mathrm{r}=0.81 ; \mathrm{P}<0.01$ and $\mathrm{r}=0.90 ; \mathrm{P}<0.01)$ and flavonoids $(\mathrm{r}=0.83 ; \mathrm{P}<0.01$ and $\mathrm{r}=0.93 ; \mathrm{P}<0.01)$ during the growing seasons 2013 and 2014 respectively (Table 3). The HAA was certainly correlated with the levels of all the main antioxidants (vitamin C, flavonoids and total phenols), but it was not the simple sum of their content. It can also depend on synergistic effect among all hydrophilic antioxidants and their interactions with other constituents of the fraction (Lenucci et al., 2006; Ilahy et al., 2011a, 2016). The higher correlation coefficient of the HAA to both total phenolics and flavonoids during the 2014 growing season can be ascribed to the massive accumulation of both compounds as a result of the heat stress.

\section{Conclusions}

The inter-annual variability of environmental factors and climatic conditions, deeply affects the phytochemical content (particularly total phenolics and flavonoids) in high-lycopene tomato berries with no or little effect on the antioxidant activity of both hydrophilic and lipophilic extracts. This reveals minimal genotype*environmental conditions interaction and therefore consistent functional quality of these cvs. Large-scale, multiyear comparisons with standard and defined agronomic practices are still needed to evaluate whether agronomic practices influence antioxidant bioactive compounds in tomato cvs.

\section{Acknowledgements}

The Author is thankful to Dr. Sabri Kanzari from the National Research Institute in Rural Engineering, Water and Forestry, Tunisia for his help in climatic data interpretation.

\section{References}

Abushita AA, Daood HG, Biacs PA. 2000. Change in carotenoids and antioxidant vitamins in tomato as a function of varietal and technological factors. Journal of Agricultural and Food Chemistry. 48: 2075-2081.

Bino RJ, De Vos CHR, Lieberman M, Hall RD, Bovy A, Jonker HH, Tikunov Y, Lommen A, Moco S, Levin I. 2005. The lighthyperresponsive high pigment- $2^{d g}$ mutation of tomato: alterations in the fruit metabolome. New Phytologist. 166 (2): 427-438.

Brandt S, Pék Z, Barna E, Lugasi A, Helyes L. 2006. Lycopene content and colour of ripening tomatoes as affected by environmental conditions. Journal of the Science of Food and Agriculture 86: 568-572.

Chandra, HM, Ramalingam S. 2011. Antioxidant potentials of peel, pulp, and seed fractions of commercially important tomato cultivars. Food Science and Biotechnology, 20: 15-21.

Chandra HM, Shanmugaraj BM, Srinivasan B, Ramalingam S. 2012. Influence of Genotypic Variations on Antioxidant Properties in Different Fractions of Tomato. Journal of Food Science 77(11): 1174-1178.

Di Mascio P, Kaiser S, Sies H. 1989. Lycopene as the most efficient biological carotenoid singlet oxygen quencher. Archives of Biochemistry and Biophysics. 274: 532-538.

Dumas Y, Dadomo M, Di Lucca G, Grolier P. 2003. Effects of environmental factors and agricultural techniques on antioxidant content of tomatoes. Journal of the Science of Food and Agriculture 83: 369-382.

Erdman JW, Ford NA, Lindshield BL. 2009. Are the health attributes of lycopene related to its antioxidant function?. Archives of Biochemistry and Biophysics 483:229-235

Fernández-García E. 2014a. Photoprotection of human dermal fibroblasts against ultraviolet light by antioxidant combinations present in tomato. Food and Function. 5: 285-290.

Fernández-García E. 2014b. Skin protection against UV-light by dietary antioxidants. Food and Function 5: 1994-2003. 
Fish WW, Perkins-Veazie P, Collins JK. 2002. A quantitative assay for lycopene that utilizes reduced volumes of organic solvents. Journal of Food Composition and Analysis. 15: 309-17.

George B, Kaur C, Khurdiya DS, Kapoor HC. 2004. Antioxidants in tomato (Lycopersicon esculentum) as a function of genotype. Food Chemistry. 84: 45-51.

Giorgi F, Lionello P. 2008. Climate change projections for the Mediterranean region. Global and Planetary Change. 63: 90104.

Hdider C, Ilahy R, Tlili I. 2013 Effect of the stage of maturity on antioxidant content and antioxidant activity of different high pigment tomato cultivars grown in Italy. In: Ilahy $\mathrm{R}(\mathrm{Ed})$ Tunisian Fruits and Vegetables. Food 7 (Special Issue 1): 1-7.

Ilahy R, Piro G, Tlili I, Riahi A, Rabaoui S, Ouerghi I, Hdider C, Lenucci MS. 2016. Fractionate analysis of the phytochemical composition and antioxidant activities in adavanced breeding lines of high-lycopene tomatoes. Food and Function 7: 574583.

Ilahy R, Riahi A, Tlili I, Hdider C, Lenucci MS, Dalessandro G. 2015 .Carotenoid content in intact plastids isolated from ordinary and high-lycopene tomato (Solanum lycopersicum L.) cultivars. Acta. Horticulturae (ISHS). 1081: 135-140.

Ilahy R, Hdider C, Tlili I. 2009. Bioactive compounds and antioxidant activity of tomato high-lycopene content advanced breeding lines. The African Journal of Plant Science and Biotechnology 3(SI1), 1-6.

Ilahy R, Hdider C, Lenucci MS, Tlili I, Dalessandro G. 2011a. Antioxidant activity and bioactive compound changes during fruit ripening of high-lycopene tomato cultivars. Journal of Food ComposItion and Analysis. 24:588-595.

Ilahy R, Hdider C, Lenucci MS, Tlili I, Dalessandro G. 2011 b. Phytochemical composition and antioxidant activity of highlycopene content tomato (Lycopersicon esculentum Mill) cultivars grown southern Italy. Scientia Horticulturae. 127 (3): 255-261.

Kahkonen MP, Hopia AI, Vuorela HJ, Rauha JP, Pihlaja K, Kujala TS, Heinonen M. 1999. Antioxidant activity of plant extracts containing phenolic compounds. Journal of Agricultural and Food Chemistry 47: 3954-3962.

Kampfenkel K, Van Montagu M, Inzè D. 1995. Extraction and determination of ascorbate and dehydroascorbate from plant tissue. Analytical Biochemistry. 225: 165-167.

Lenucci MS, Cadinu D, Taurino M, Piro G, Giuseppe D. 2006. Antioxidant composition in cherry and high-pigment tomato cultivars. Journal of Agricultural and Food Chemistry. 54: 2606-2613.

Lenucci MS, Serrone L, De Caroli M, Fraser PD, Bramley P, Piro G, Dalessandro G. 2012. Isoprenoid, lipid, and protein contents in intact plastids isolated from mesocarp cells of traditional and high-pigment tomato cultivars at different ripening stages. Journal of Agricultural and Food Chemistry. 60: 1764-1775.

Levin I, De Vos CHR, Tadmor Y, Bovy A, Liberman M, OrenShamir M. 2006. High-pigment tomato mutants- more than just lycopene (a review). Israel Journal of Plant Sciences. 54: 179190.

Martínez-Valverde I, Periago MJ, ProvanG, Chesson A. 2002. Phenolic compounds, lycopene and antioxidant activity in commercial varieties of tomato (Lycopersicon esculentum). Journal of the Science of Food and Agriculture. 82: 323-330.
Mochizuki T, Kamimura S, 1984. Inheritance of vitamin C content and its relation to other characters in crosses between hp and og varieties of tomatoes. In 9th Meeting of the EUCARPIA Tomato Workshop, Wageningen, The Netherlands; EUCARPIA Tomato Working Group: Wageningen, The Netherlands, 8-13.

Mustilli AC, Fenzi F, Gliento R, Alfano F, Bowler, C, 1999. Phenotype of the tomato high pigment- 2 mutant is caused by a mutation in the tomato homologue of de-etiolated 1. the Plant Cell. 11: 145-157.

Pellegrini N, Colombi B, Salvatore S, Brenna O, Galaverna G, Del Rio D, 2007. Evaluation of antioxidant capacity of some fruit and vegetable foods: Efficiency of extraction of a sequence of solvents. Journal of the Science of Food and Agriculture. 87: 103-111.

Phillips KM, Tarrgó-Trani MT, Gebhardt SE, Exler J, Patterson KY., Haytowitz, DB, Pehrsson PR, Holden JM. 2010. Stability of vitamin $\mathrm{C}$ in frozen raw fruit and vegetable homogenates Journal of Food Composition and Analysis. 23: 253-259.

Qu M, Nan X, Gao Z, Guo B, Liu B, Chen Z. 2013 Protective effects of lycopene against methylmercury-induced neurotoxicity in cultured rat cerebellar granule neurons. Brain Research. 1540: 92-102.

Raffo A, Cherubino L, Vincenzo F, Ambrozino P, Salucci M, Gennaro L, Bugianesi R, Giuffrida F, Quaglia G. 2002. Nutritional value of cherry tomatoes (Lycopersicon esculentum $\mathrm{Cv}$. Naomi F1) harvested at different ripening stages. Journal of Agricultural and Food Chemistry. 50: 6550-6556.

Rice-Evans C.A, Sampson J, Bramley PM, Holloway DE. 1997. Why do we expect carotenoids to be antioxidants in vivo? Free Radical Research. 26: 381-98.

Siddiqui,MW, Chakraborty I, Mishra P, Hazra P. 2014. Bioactive attributes of tomato possessing dg, ogc and rin genes. Food and Function. 5, 936-943.

Soares NCP, Teodoro AJ, Oliveira FL, Takiya CM, Junior AP, Nasciutti LE, Lotsch PF, Granjeiro JM, Ferreira, LB, Pereira Gimba ER., Borojevic R. 2014. Lycopene induce apoptosis in human prostate cells and alters the expression of Bax and Bcl-2 genes. LWT- Food Science and Technology. 59: 1290-1297.

Spanos GA, Wrolstad RE. 1990. Influence of processing and storage on the phenolic composition of Thompson Seedless grape juice. Journal of Agricultural and Food Chemistry. 38: 1565-1571.

Takashima M, Shichiri M, Hagihara Y, Yoshida Y, Niki E. 2012. Capacity of peroxyl radical scavenging and inhibition of lipid peroxidation by $\beta$-carotene, lycopene, and commercial tomato juice. Food and Function 3 (11): 1153-1160.

Thaipong K, Boonprakob U, Crosby K, Cisneros-Zevallos L, Byrbe DH. 2006. Compraison of ABTS, DPPH, FRAP and ORAC assays for estimating antioxidant activity from guava fruit extracts. Joural of Food ComposItion and Analysis. 19: 669657.

Toor RK, Savage GP, 2005. Antioxidant activity in different fraction of tomatoes. Food Research International. 38: 487-494.

Wann EV. 1997. Tomato germplasm lines T4065, T4099, T5019, and T5020 with unique genotypes that enhance fruit quality. Horticultural Science. 32, 747-748.

Zhishen J, Mengcheng T, Jianming W, 1999. The determination of flavonoid contents in mulberry and their scavenging effects on superoxide radicals. Food Chemistry. 64 (4), 555-559. 